\title{
Measurements of Volatile Organic Compounds Using Proton Transfer Reaction - Mass Spectrometry during the MILAGRO 2006 Campaign
}

\author{
E. C. Fortner ${ }^{1, *}$, J. Zheng ${ }^{1}$, R. Zhang ${ }^{1}$, W. Berk Knighton ${ }^{*}$, R. M. Volkamer ${ }^{2,3}$, P. Sheehy ${ }^{2}$, L. Molina ${ }^{2}$, and M. André ${ }^{4}$ \\ ${ }^{1}$ Department of Atmospheric Sciences, Texas A\&M University, College Station, Texas 77843, USA \\ ${ }^{2}$ Molina Center for Energy and the Environment, La Jolla, California and Massachusetts Institute of Technology, Cambridge, \\ Massachusetts, USA \\ ${ }^{3}$ Department of Chemistry and Biochemistry, University of Colorado at Boulder, Boulder, CO, USA \\ ${ }^{4}$ Institute of Environmental Physics, University of Heidelberg, INF 229, 69120 Heidelberg, Germany \\ * now at: Department of Chemistry and Biochemistry, Montana State University, Bozeman, Montana, USA
}

Received: 7 April 2008 - Published in Atmos. Chem. Phys. Discuss.: 13 June 2008

Revised: 24 September 2008 - Accepted: 9 December 2008 - Published: 21 January 2009

\begin{abstract}
Volatile organic compounds (VOCs) were measured by proton transfer reaction - mass spectrometry (PTRMS) on a rooftop in the urban mixed residential and industrial area North Northeast of downtown Mexico City as part of the Megacity Initiative - Local and Global Research Observations (MILAGRO) 2006 field campaign. Thirty eight individual masses were monitored during the campaign and many species were quantified including methanol, acetaldehyde, toluene, the sum of $\mathrm{C}_{2}$ benzenes, the sum of $\mathrm{C}_{3}$ benzenes, acetone, isoprene, benzene, and ethyl acetate. The VOC measurements were analyzed to gain a better understanding of the type of VOCs present in the MCMA, their diurnal patterns, and their origins. Diurnal profiles of weekday and weekend/holiday aromatic VOC concentrations showed the influence of vehicular traffic during the morning rush hours and during the afternoon hours. Plumes including elevated toluene as high as 216 parts per billion (ppb) and ethyl acetate as high as $183 \mathrm{ppb}$ were frequently observed during the late night and early morning hours, indicating the possibility of significant industrial sources of the two compounds in the region. Wind fields during those peak episodes revealed no specific direction for the majority of the toluene plumes but the ethyl acetate plumes arrived at the site when winds were from the Southwest or West. The PTR-MS measurements combined with other VOC measuring techniques
\end{abstract}

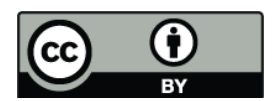

Correspondence to: $\mathrm{R}$. Zhang

(zhang@ariel.met.tamu.edu) at the field site as well as VOC measurements conducted in other areas of the Mexico City Metropolitan Area (MCMA) will help to develop a better understanding of the spatial pattern of VOCs and its variability in the MCMA.

\section{Introduction}

Mexico City Metropolitan Area (MCMA) is the location of some of the most severe air pollution in the world. The city has a population of 18 million people and is home to 4 million vehicles and 45000 industries (Molina et al., 2002; CAM, 2006). Mexico City is located in the tropics at a high elevation, further enhancing photochemical activity and ozone production. Another factor contributing to the air pollution problem in this area is that the city lies in a valley surrounded by mountains and thermal inversions are common during the morning hours. Daily activities in the city lead to the emission of volatile organic compounds (VOCs) which react with nitrogen oxides $\left(\mathrm{NO}+\mathrm{NO}_{2}=\mathrm{NO}_{\mathrm{x}}\right)$ emitted primarily through combustion sources. This interaction leads to production of $\mathrm{O}_{3}$, secondary organic aerosols, and other toxic chemicals through photochemical processes (Tie et al., 2001; Zhang et al., 2003; Lei et al., 2004). During the late 1980s and early 1990s, the Mexican one-hour air quality standard of 110 parts per billion (ppb) of $\mathrm{O}_{3}$ has been violated in approximately $80 \%$ of the days annually and the maximum $\mathrm{O}_{3}$ values of over $300 \mathrm{ppb}$ have been recorded (INE, 2000).

Published by Copernicus Publications on behalf of the European Geosciences Union. 
Substantial improvement in air quality has been achieved after implementation of control strategies by the Mexico government (Molina et al., 2009).

While measurements of ozone and $\mathrm{NO}_{\mathrm{x}}$ are common in Mexico City, measurements of VOCs have been much less common and are important for understanding ozone and secondary organic aerosol formation (Molina et al., 2002; Zhang et al., 2004a; Lei et al., 2007, Tie et al., 2007). A study by Arriaga-Colina et al. (2004) comparing morning measurements of $\mathrm{VOC} / \mathrm{NO}_{\mathrm{x}}$ and $\mathrm{CO} / \mathrm{NO}_{\mathrm{x}}$ ratios with ratios in the 1998 emissions inventory (CAM, 2001) suggested that the $\mathrm{VOC} / \mathrm{NO}_{\mathrm{x}}$ and $\mathrm{CO} / \mathrm{NO}_{\mathrm{x}}$ ratios in the emissions inventory may be underestimated by a factor of 2 to 3 in MCMA. Modeling work by West et al. (2004) compared measured non-methane hydrocarbons (NMHCs) to modeled NMHCs and achieved the best fit by increasing the VOC emissions by a factor of three. While Arriaga-Colina et al. (2004) and West et al. (2004) both suggested underestimated VOCs in the emissions inventory, flux measurements conducted during MCMA 2003 campaign utilizing a PTR-MS instrument by Velasco et al. (2005) showed a fairly good agreement between emissions inventory and measurements. The Megacity Initiative - Local and Global Research Observations (MILAGRO) 2006 campaign represented an unprecedented international effort to observe and quantify the fate of anthropogenic pollutants emitting from the world's second largest city. In this paper we report VOC measurements using a proton transfer reaction - mass spectrometer (PTR-MS) deployed and operated during the MILAGRO field. There are several advantages using PTR-MS in VOC measurements. Although PTR-MS cannot measure smaller saturated hydrocarbons, most highly reactive VOCs, e.g., alkenes and aromatics, can be detected by PTR-MS. Also, unlike GC based VOC measurement techniques, PTR-MS does not require pre-treatment of air samples and can continuously monitor VOCs of interest with a high temporal resolution. This method is especially useful in monitoring rapid changes where some highly reactive VOCs are efficiently removed photochemically, determining constant VOC emission sources, and capturing intermittent VOC hot spots that are often missed by GC technique. Our measurements, in conjunction with other VOC measurements performed in the MILAGRO 2006 campaign, can be used to better elucidate the VOC emissions and chemistry in the Mexico City area. In a separate publication, we have reported measurements of $\mathrm{HNO}_{3}$ during the MILAGRO 2006 campaign (Zheng et al., 2008).

\section{Experimental methods}

In March 2006, we employed a PTR-MS instrument (Ionicon) at the T0 site to conduct measurements of VOCs in Mexico City during the MILAGRO 2006 campaign. The measurements were conducted on the rooftop of a five-story building located at the Instituto Mexicano del Petroleo (IMP) facility, approximately 7 miles North-Northeast of downtown Mexico City. The T0 site represented one of three supersites involved in the MILAGRO 2006 project. The other two supersites, named T1 and T2, were located farther from Mexico City to the Northeast of the city. In addition to the supersites, there was also a flux tower constructed in downtown Mexico City and a mobile research van which moved to various sites around the MCMA. The PTR-MS instrument was also utilized both at the flux tower and the mobile van. The T1 and $\mathrm{T} 2$ supersites used canister samples analyzed by gas chromatography - flame ionization detection (GC-FID), differential optical absorption spectroscopy (DOAS), and proton transfer - ion trap - mass spectrometry (PT-IT-MS) to measure VOCs. Certain VOCs were also measured at the T0-IMP site using DOAS, canisters, and GC methods, in addition to the PTR-MS.

Online measurements of VOCs were conducted using the PTR-MS at T0-IMP from 5-23 March and 26-31 March. The system was inoperable from 23-26 March due to a condensation problem. The PTR-MS sampled continuously between day and night. Throughout the campaign, a drift tube pressure was maintained at 2.1 millibars and an $E / N$ ratio of 115 Townsend $\left(1 \mathrm{Td}=10^{17} \mathrm{~V} \mathrm{~cm}^{2}\right.$ molecule $\left.^{-1}\right)$ was utilized, where $E$ is the electronic field strength in $\mathrm{V} \mathrm{cm}^{-1}$ and $N$ is the number concentration of the buffer gas in molecule $\mathrm{cm}^{-3}$. There were a suite of 38 masses sampled sequentially by the PTR-MS during the majority of the field campaign. Each mass was monitored for two seconds so that the time between samples was approximately 76 seconds. Spectral scans from mass 21-250 were also conducted for one half hour every two hours to survey mass peaks that might have been missed while in the single ion scan mode. Background checks were performed for approximately $15 \mathrm{~min}$ once every three hours. Calibrations were conducted daily during the first half of the field campaign and once every other day toward the latter stages of the field campaign after it had been determined that the system was relatively stable and there was a need to increase the total measurement time.

The inlet was constructed of 0.25 inch outer diameter (OD) perfluoroalkoxy (PFA) tubing with a length of $14 \mathrm{ft}$ and was pumped by a diaphragm pump at 30 standard liters per minute (slpm), maintaining a residence time of $2-3 \mathrm{~s}$ in the inlet. A small amount of the inlet flow (50-200 standard cubic centimeters per minute, sccm) was diverted to the PTRMS at a PFA tee upstream of the pump. This flow then passed directly into the PTR-MS or was diverted into a catalytic converter if the background sample was taken at the time.

The instrument background was determined by passing the sample air through a catalytic converter en route to the PTR-MS. Background checks typically lasted 10 cycles and at a given time the background was the average of the backgrounds determined before and after the measurements. The use of a catalytic converter enabled background determinations while maintaining the ambient relative humidity. 
Calibrations of the PTR-MS instrument during MILAGRO 2006 were conducted using a custom mix calibration gas cylinder (Spectra Gas) containing propene, 1-butene, acetone, isoprene, methyl ethyl ketone, benzene, toluene, mxylene, 1,3,5-trimethylbenzene, and $\alpha$-pinene. The mixing ratio of the calibrated gases varied between 2 and $20 \mathrm{ppb}$. The carrier gas for the calibration was ambient air which passed through the catalytic converter. The calibration flow connected with the inlet through a PFA fitting. Alternatively, VOC concentrations were calculated from the known ionmolecular reaction time and rate constants with the hydronium ions $\left(\mathrm{H}_{3} \mathrm{O}^{+}\right)$(Zhao et al., 2004a, b). The performance of the PTR-MS was found to be slightly variable during the MILAGRO field campaign and for this reason the calibration curves from the preceding and following calibrations at a given time were employed rather than using an average of all calibration curves developed throughout the field campaign.

\section{Results and discussion}

\subsection{Local meteorological details}

Surface winds at the IMP site obtained by Argonne National Laboratory were characterized by a strong diurnal cycle with wind speeds between 0.5 and $3.0 \mathrm{~m} \mathrm{~s}^{-1}$ during the early morning hours (00:00-08:00 local time, LT). Winds gradually increased throughout the day corresponding with the developing boundary layer and attained their maximum value of 5-9 $\mathrm{m} \mathrm{s}^{-1}$ in the late afternoon and early evening time periods (15:00-19:00 LT) (Shaw et al., 2007). During the campaign, wind direction was variable and a trend was difficult to identify, although there appeared to be a slight preference for a wind from either the East or West during the early morning hours. Preliminary analysis of profiler data gathered by the team from the University of Alabama-Huntsville at the IMP site indicated early morning boundary layer heights of 300$500 \mathrm{~m}$ and late afternoon boundary layer heights of 3000$4000 \mathrm{~m}$. These measurements were in agreement with those reported previously by De Foy et al. (2005), who found surface temperature inversions below $500 \mathrm{~m}$ for most nights and daytime boundary layer growth to $4000 \mathrm{~m}$ during the MCMA 2003 campaign. Low temperatures in the morning were typically $50-55^{\circ} \mathrm{F}$ and the high temperatures were typically between 75 and $80^{\circ} \mathrm{F}$. Relative humidity ranged from $50-80 \%$ in the early morning hours and $10-40 \%$ during the afternoon. No precipitation occurred during the first two and half weeks of the field campaign, but during the last one and half weeks of the campaign there were several occurrences of scattered thunderstorms in the late afternoon.

\subsection{Interpretation of mass spectral assignments}

\subsubsection{Mass 33}

The ion signal at mass 33 is attributed to methanol. There are no known hydrocarbons which interfere with the measurement of methanol at mass 33 (de Gouw and Warneke, 2007; Rogers et al., 2006). Methanol was not calibrated during the field campaign and a rate constant of $2 \times 10^{-9} \mathrm{~cm}^{3} / \mathrm{s}$ was used to determine its concentration.

\subsubsection{Mass 42}

Mass 42 is assigned to acetonitrile. Some small alkanes may contribute to the signal at mass 42 by reacting with $\mathrm{O}_{2}^{+}$. However, this interference usually is found to be minor (de Gouw and Warneke, 2007).

\subsubsection{Mass 45}

The signal at mass 45 is attributed to acetaldehyde. Carbon dioxide $\left(\mathrm{CO}_{2}\right)$ was found to weakly contribute to the ion signal at mass 45 , with 1 ppmv $\mathrm{CO}_{2}$ equivalent to $1 \mathrm{pptv}$ acetaldehyde (Rogers et al., 2006). In addition, because $\mathrm{CO}_{2}$ was not removed by the catalytic converter, the $\mathrm{CO}_{2}$ interference should be accounted for by background checks. The $\mathrm{CO}_{2}$ interference could play a more significant role in a clean air mass when attempting to measure low mixing ratios of acetaldehyde but this was not the case at the urban T0 site. Calibrations were conducted with this compound throughout the field campaign.

\subsubsection{Mass 59}

Acetone, propanal, and glyoxal are all likely detected at mass 59 (Rogers et al., 2006). Calibrations of acetone were conducted throughout the field campaign and the signal at mass 59 was quantified based on the acetone calibrations. The signal at mass 59 may be considered as the lower limit of the sum of these three species, since glyoxal has a reaction rate constant considerably lower than that of propanal and acetone (Zhao and Zhang, 2004a).

\subsubsection{Mass 69}

Isoprene is measured at mass 69 . Several other species also have been reported to be detected at mass 69 , such as methyl butanal, ethyl vinyl alcohol, and furan (Christian et al., 2004; Karl et al., 2001). However, isoprene was often found as the dominant species at mass 69 within various kinds of air masses (de Gouw and Warneke, 2007). The PTR-MS was calibrated with isoprene standards throughout the campaign.

\subsubsection{Mass 73}

Methyl ethyl ketone (MEK) can be detected at mass 73 (de Gouw and Warneke, 2007). Substantial mass 73 signals were 

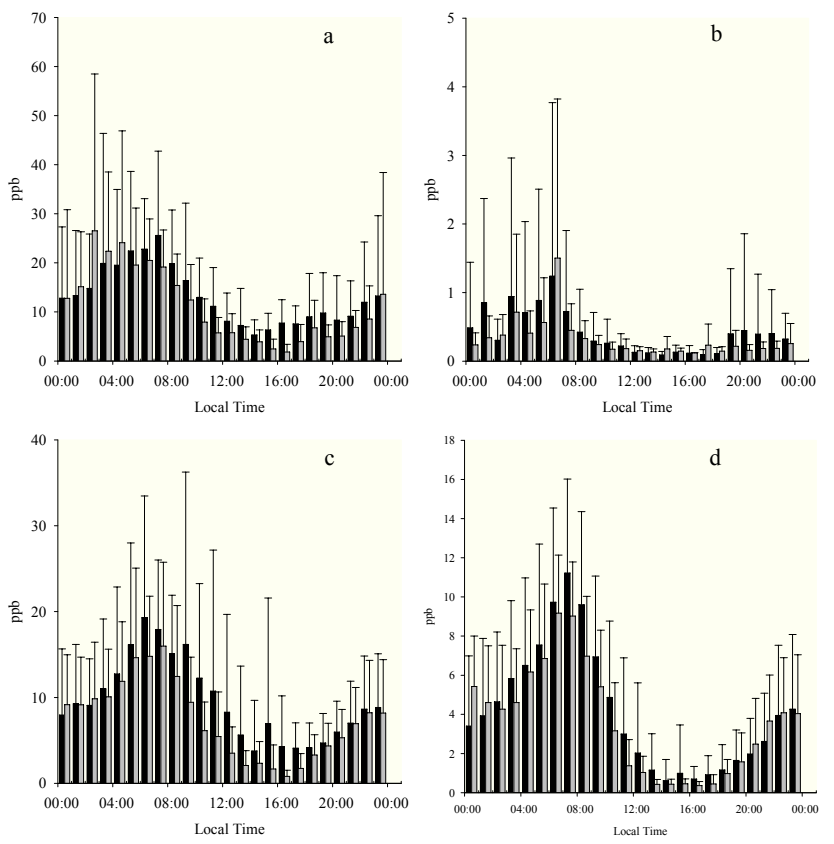

Fig. 1. The diurnal profiles of (a) toluene (m/e 93), (b) styrene (m/e 105), (c) $\mathrm{C}_{2}$-benzenes (m/e 107), and (d) $\mathrm{C}_{3}$-benzenes (m/e 121) for both week days (black) and weekend/holidays (gray).

also assigned to methyl glyoxal, one of the major products from $\mathrm{OH}$ initiated oxidations of aromatic compounds (Zhao et al., 2005), which were observed with significant concentrations during the MILAGRO 2006 campaign. Water cluster, $\mathrm{H}_{3} \mathrm{O}^{+}\left(\mathrm{H}_{2} \mathrm{O}\right)_{3}$, can also be detected at mass 73 , but under the experimental conditions no significant interference from water cluster was found during background checks throughout the field campaign. Mass 73 was calibrated with MEK standards during the field campaign and the same calibration factor was applied for both MEK and methyl glyoxal.

\subsubsection{Mass 79}

This mass is primarily attributed to benzene. Although there are possible contributions to mass 79 due to fragmentations of ethyl- and propyl- benzenes, the magnitude of the fragmentation is found to be minor when the PTR-MS is operated at a reduced $\mathrm{E} / \mathrm{N}$ ratio (de Gouw and Warneke, 2007). In the present work, this ratio was maintained at $115 \mathrm{Td}$ throughout the campaign. Benzene was calibrated throughout the field campaign.

\subsubsection{Mass 89}

The ion observed at this mass is attributed to ethyl acetate. Mass 89 correlated well with masses 43 and 61 during the field campaign, which was also observed during laboratory tests with ethyl acetate samples. Rogers et al. (2006) observed ethyl acetate during the MCMA 2003 campaign and the finding was further confirmed by gas chromatography measurements. Ethyl acetate was not calibrated during the campaign and a rate constant of $2 \times 10^{-9} \mathrm{~cm}^{3} / \mathrm{s}$ was used to quantify its concentration. The fragmentation was accounted for in the data analysis. There are other species such as butyric acid that also likely contribute to mass 89 , and their presence cannot be ruled out.

\subsubsection{Mass 93}

The ion observed at this mass is attributed to toluene. Fragmentation of monoterpenes can present a minor interference (de Gouw and Warneke, 2007). Warneke et al. (2003) found about $7 \%$ of monoterpenes fragmented to mass 93 . The monoterpene signal at mass 137 was consistently much lower than the mass 93 signal during the field campaign. Toluene was calibrated throughout the field campaign.

\subsubsection{Mass 105}

Both styrene and peroxy isobutyryl nitrate (PiBN) can be detected at mass 105 . Styrene is mostly emitted from petrochemical industry sources and PiBN is usually found in aged plumes (de Gouw and Warneke, 2007). Considering the petrochemical facilities near the T0 observation site, we assigned the mass 105 as styrene.

\subsection{VOC diurnal profiles}

The diurnal profiles for four selected aromatic VOCs are shown in Fig. 1. The measurements for the selected aromatic VOCs that occurred within each hourly time are summed and averaged for weekdays and weekends/holidays separately. 20 and 21 March 2006 were national holidays and non-working days for many citizens of Mexico City so that these dates were considered to better representing the weekend activity. Totally, the measurements were conducted on 16 weekdays and 6 weekends/Holidays. Traffic conditions in the MCMA area were visually lightened during weekends or holidays, but industrial facilities in this region typically operated on a basis of twenty-four hours a day and seven days a week (Stephens et al., 2008).

The aromatics are represented by toluene at mass 93 , styrene at mass 105, the sum of $\mathrm{C}_{2}$ benzenes including xylenes at mass 107, and the sum of $\mathrm{C}_{3}$ benzenes at mass 121. On weekdays aromatics attained their highest concentration from 06:00-07:00 LT for masses 105 (about 1.3 ppb) and 107 and 07:00-08:00 LT for masses 93 and 121. On weekends/holidays the aromatics detected at masses 105 , 107 , and 121 peaked at the similar times as their weekday highs, while the mass 93 reached the maximum value during the 02:00-03:00 LT period. The weekday peaks for masses 93,107 , and 121 were about $26,19,11 \mathrm{ppb}$, respectively, and were slightly higher that those of the corresponding weekend/holiday values. 

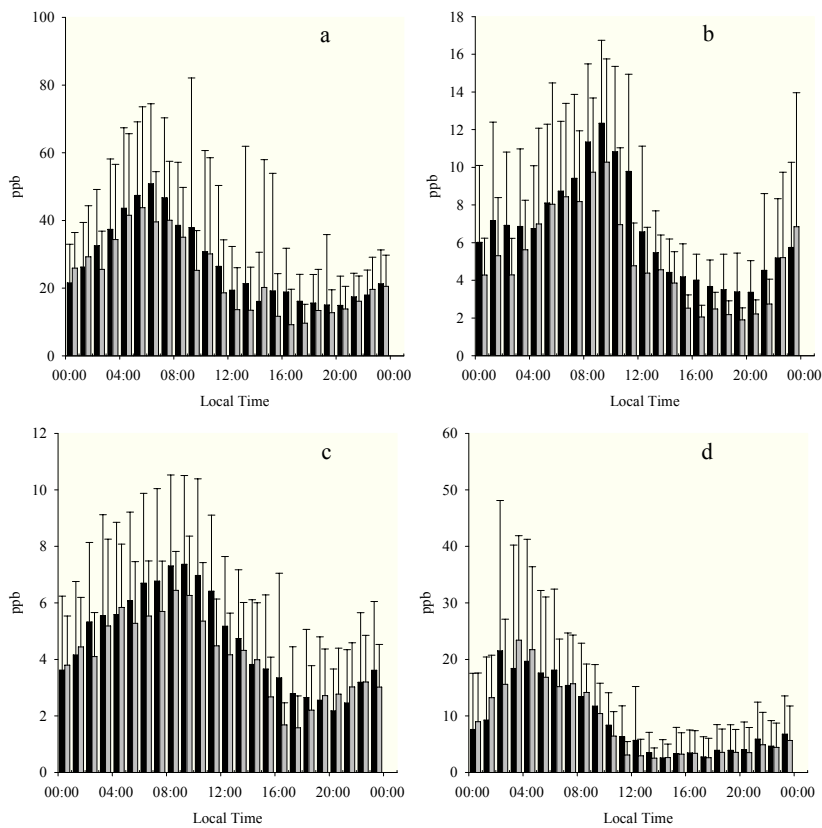

Fig. 2. The diurnal profiles of (a) methanol (m/e 33), (b) acetaldehyde (m/e 45), (c) methyl glyoxal + MEK (m/e 73), and (d) ethyl acetate (m/e 89) for both week days (black) and weekend/holidays (gray).

Four selected oxygenated VOCs are depicted in Fig. 2, including methanol at mass 33 , acetaldehyde at mass 45 , the sum of methyl ethyl ketone (MEK) and methylglyoxal at mass 73 , and ethyl acetate at mass 89 . The weekday mass 89 reached the maximum of about $35 \mathrm{ppb}$ during 07:0008:00 LT. The masses 45 and 73 peaked later in the morning during the 09:00-10:00 LT, with the maximum weekday values of about 12 and $7 \mathrm{ppb}$, respectively. The ethyl acetate mass 89 reached a peak (about $21 \mathrm{ppb}$ for the weekday value) during the evening hour of 02:00-03:00 LT. The mass 45 peaked during the same time period on weekdays and weekends/holidays, while mass 73 during weekends/holidays attained the daily peak one hour earlier than weekdays. The mass 89 during the weekends/holidays time period reached the maximum from 03:00 to 04:00 LT, about one hour later than its weekday peak. Except for mass 89, the other three oxygenated VOCs showed a larger weekday peak than the weekend/holiday peak. For methanol, its diurnal profile was consistent with other OVOCs. It is possible that those OVOCs shared some similar formation mechanisms. Because vegetation is scarce within the city, especially in the northern portion, the biogenic components are negligible in the city. On the basis of the present measurements, it was rather inconclusive on the contribution of automobile emissions to the methanol observation.

The differences between weekday and weekend diurnal patterns for the VOCs were best characterized as subtle yet detectable for most species. All species, particularly the aro-
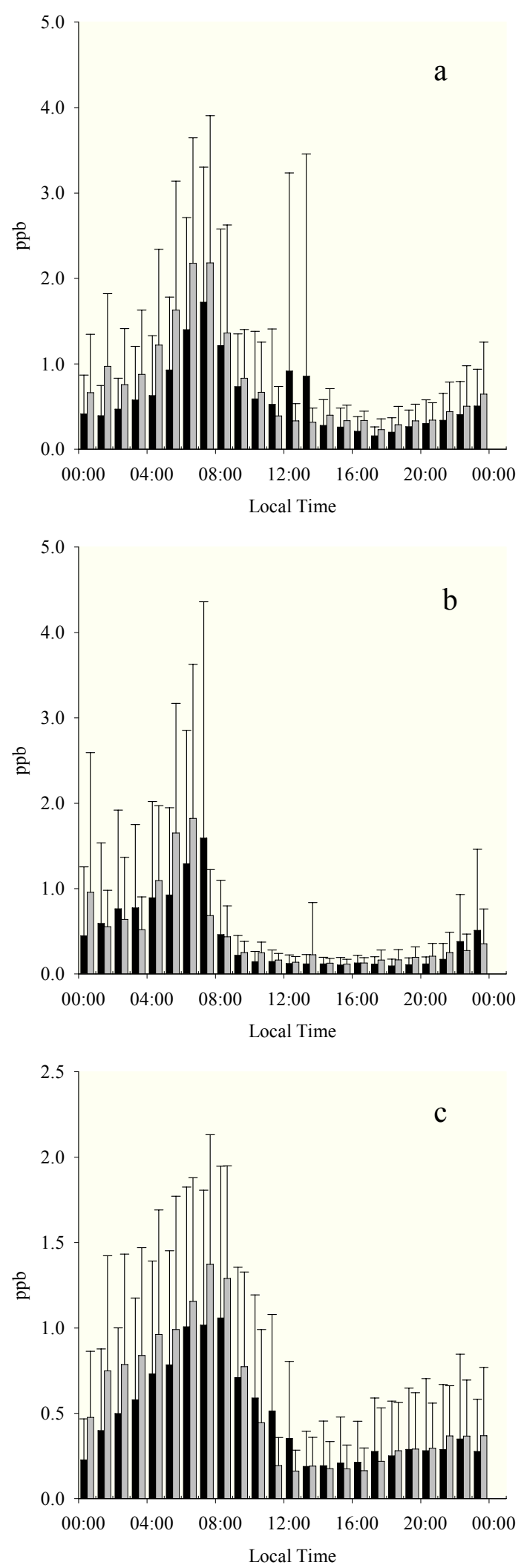

Fig. 3. The diurnal profiles of (a) isoprene (m/e 69), (b) monoterpenes (m/e 137), and (c) acetonitrile (m/e 42) for both week days (black) and weekend/holidays (gray). 
Table 1. Summary of occurrences of toluene plumes observed during MILAGRO 2006: The magnitudes, backgrounds (mixing ratios outside of the plume), wind direction, wind speed, time of occurrence, duration, date and day of week pertaining to the ten highest peaks.

\begin{tabular}{crrcrrrr}
\hline $\begin{array}{c}\text { Mixing Ratio } \\
(\mathrm{ppb})\end{array}$ & $\begin{array}{r}\text { Baseline } \\
(\mathrm{ppb})\end{array}$ & $\begin{array}{r}\text { Date } \\
(\mathrm{Mar})\end{array}$ & Local Time & $\begin{array}{r}\text { Duration } \\
(\mathrm{min})\end{array}$ & Day & $\begin{array}{r}\text { Wind Dir. } \\
\text { (Degree) }\end{array}$ & $\begin{array}{r}\text { Wind Speed } \\
(\mathrm{m} / \mathrm{s})\end{array}$ \\
\hline 229 & 12.5 & 17 & $02: 53-03: 35$ a.m. & 42 & Friday & 109 & 0.6 \\
215 & 13.8 & 11 & $12: 49-01: 17$ a.m. & 28 & Saturday & 239 & 0.5 \\
202 & 23 & 21 & $04: 29-04: 56$ a.m. & 27 & Tuesday & 246 & 0.86 \\
191 & 20 & 12 & $01: 53-03: 18$ a.m. & 85 & Sunday & 183 & 0.96 \\
185 & 8 & 26 & $11: 22-11: 57$ p.m. & 35 & Sunday & 215 & 0.6 \\
177 & 7 & 9 & $11: 13-11: 34$ p.m. & 21 & Thursday & 221 & 1.08 \\
142 & 19.5 & 8 & $01: 14-01: 31$ a.m. & 17 & Wednesday & 148 & 1.27 \\
124 & 30 & 7 & $07: 06-07: 38$ a.m. & 32 & Tuesday & N/A & N/A \\
124 & 26 & 31 & $04: 26-04: 39$ a.m. & 13 & Friday & N/A & N/A \\
123 & 11 & 6 & $03: 36-05: 20$ a.m. & 104 & Monday & N/A & N/A \\
\hline
\end{tabular}

matics, had lower mixing ratios during the daylight hours on weekends compared with the same time periods on weekdays. During the evening hours, methanol and $\mathrm{C}_{2}$ benzenes showed lower weekend mixing ratios, while toluene and ethyl acetate showed little difference or even slightly higher mixing ratios on the weekends.

Figure 3 shows the diurnal profiles of isoprene at mass 69 and monoterpenes at mass 137, and a biomass-burning marker, acetonitrile at mass 42. All three species peaked in the morning hour of 07:00-09:00 LT. The daily peak values for masses 69,137 , and 42, were about 1.9, 1.6, and $1.2 \mathrm{ppb}$, respectively. Both isoprene and monoterpenes present similar profiles as aromatics and given that vegetation is scarce within the city, particularly at the north sector, we believe they are not biogenic in origin. This is consistent with the results obtained during the MCMA 2003 campaign, when Velasco et al. (2007) found that biogenic component was negligible within the urban core and isoprene was originated from automobile exhausts. Although $\alpha$ - and $\beta$-pinenes are the major biogenic monoterpenes in the troposphere, conifers are very scarce around the IMP site. It is very likely other monoterpenes, such as limonene widely used in cosmetic products and solvents for cleaning purpose, contribute to mass 137.

Both isoprene and monoterpenes are destroyed by reactions with the hydroxyl radicals $\mathrm{OH}$ during the daytime hours (Lei et al., 2000; Zhang et al., 2002a; Fan et al., 2005) and react with $\mathrm{O}_{3}$ and $\mathrm{NO}_{3}$ at night (Suh et al., 2001; Zhang et al., 2002b). In the MCMA, nighttime $\mathrm{O}_{3}$ was often depleted by overwhelming fresh NO emissions. Thus, isoprene and monoterpenes could build up during night, but was scavenged quickly after sunrise. The mass 42 was a biomassburning marker and several biomass-burning events were visually identified during the MCMA 2006 campaign. The profile of mass 42 was likely controlled by the physical mixing processes, i.e., variations in the boundary layer height. Inter- estingly, mass 42 was higher during weekends/holidays than week days, which might indicate that mass 42 was also emitted from domestic biomass burning, such as cooking fire. Because mass 69 also showed a similar variation as mass 42 , we speculated that both masses likely shared some common sources. Because of their high reactivity with $\mathrm{OH}$, isoprene and pinenes can contribute to $\mathrm{O}_{3}$ and secondary organic aerosol formation in the urban areas (Li et al., 2007).

All of the species had elevated morning mixing ratios, which decreased with the boundary layer development during the course of the day, indicating that VOCs were produced in the Mexico City urban area. The $\mathrm{C}_{2}$ and $\mathrm{C}_{3}$ benzenes showed the diurnal profiles consistent with a traffic based emission source. The diurnal profile of toluene indicated both characteristics of a traffic based emission source as well as a periodically intense nighttime source which was unrelated to the volume of traffic. This source is likely industrial in nature, and further studies are needed to investigate VOC emissions by factories in this area to determine the location of this source and the magnitude of its impact. Ethyl acetate displayed a diurnal profile, showing that its emissions were clearly related to industrial activity during the evening hours.

\subsection{VOC plumes of interest}

The PTR-MS instrument sequentially scanned 38 masses throughout the majority of the MILAGRO 2006 field campaign. During the evening hours most masses had increased mixing ratios and this could generally be attributed to the decrease in the mixed layer height overnight. Methanol showed the largest mixing ratio during the evening on average, typically rising above $50 \mathrm{ppb}$. This might not be surprising, considering that the average methanol in the daytime was approximately $10 \mathrm{ppb}$ and the boundary layer increased in height by a factor of ten during the day. There were two species in particular that displayed increases in their mixing 

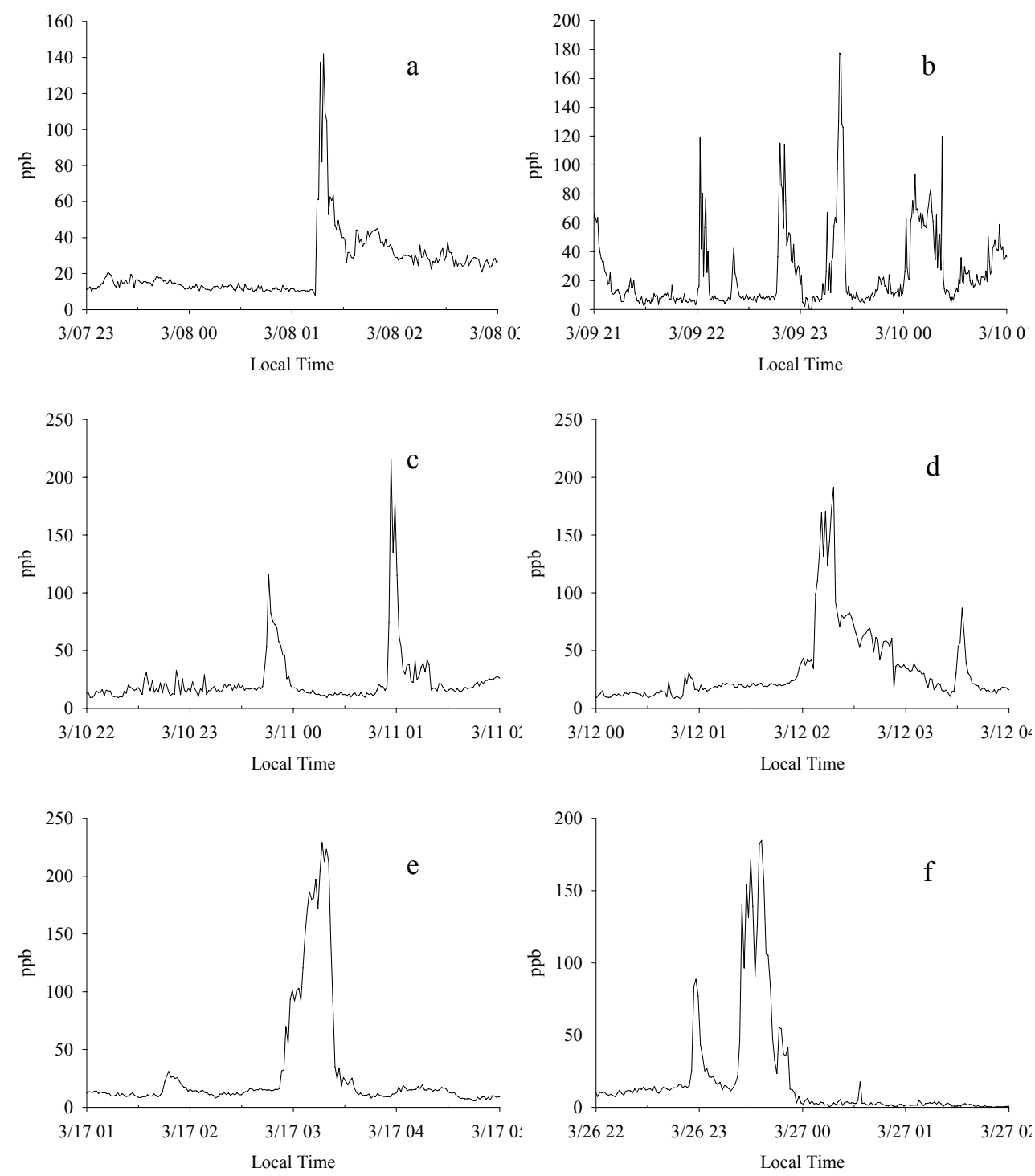

Fig. 4. Six overnight toluene plumes observed during the MILAGRO 2006 at T0 on 8 (a), 10 (b), 11 (c), 12 (d), 17 (e), and 27 (f) March.

ratios by a factor of ten or more during time periods ranging from 10-140 min during the nighttime and early morning hours. These species were toluene and ethyl acetate.

\subsubsection{Toluene}

Mixing ratios of toluene higher than $50 \mathrm{ppb}$ were encountered for 14 of the 20 evenings that the PTR-MS sampled sequentially in single ion monitor mode. Table 1 summarizes the peak concentration, time of occurrence, duration, date and day of week pertaining to the toluene plumes with the ten highest magnitudes. It is evident that the elevated toluene plumes primarily occurred during the periods of light traffic activity in the region. Only one plume coincided with the typical morning high traffic times between 06:00-09:00 LT. The remaining 9 peaks happened between the hours of 23:00-06:00 LT and only one of these peaks happened during the transitional period from light to heavy traffic that occurred between 05:00-06:00 LT. Forty percent of these peaks happened during weekends and holidays.

Figure 4 displays a series of toluene plumes. The gaps in the measurements were attributed to the periods for collection of the instrument background. For example, on March 17, 2006, a toluene plume occurred between 02:50 and 03:25 a.m., with a peak concentration approaching $230 \mathrm{ppb}$. It is worth noting that while PTR-MS measures the signal at a given mass and there are likely masses of different species contributing and complicating the assignment of the mass peak (Warneke et al., 2003; de Gouw et al., 2003a, b; Fortner et al., 2004). As discussed above, several laboratory and field studies have evaluated the assignment of the mass 93 to 


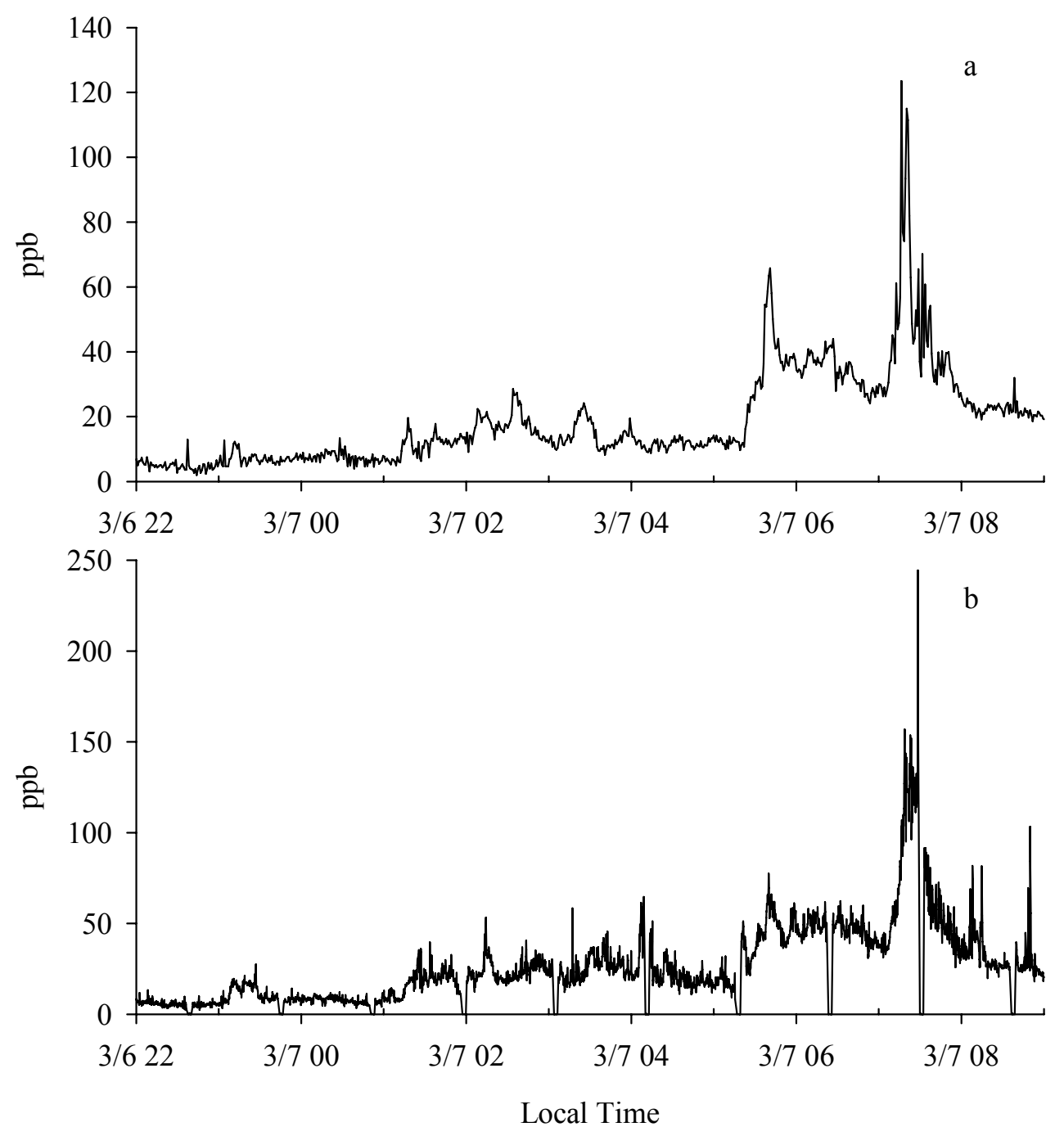

Fig. 5. ntercomparison of toluene observed at T0 (a) and on the Aerodyne Mobile Lab (b) on 7 March. Gaps in (b) were due to background checks.

toluene and a limited number of species (chloroacetone, $\alpha$ pinene and $\beta$-pinene) have been found to fragment to mass 93 (Warneke et al., 2003; de Gouw et al., 2003a, b). However, our measurements showed no indication of the presence of those species at the time of the plumes as their parent ions were monitored by the PTR-MS and found to be below $0.5 \mathrm{ppb}$ in all cases. No other masses were found to rise in correlation with the mass 93 plumes, indicating that toluene appeared to be the only VOC within the plumes.

Of the seven episodes that occurred during periods with available wind data three appeared to have wind fields that were relatively consistent in their direction and magnitude. The episodes of the 9, 12 and 21 of March featured winds from $221^{\circ}, 183^{\circ}$ and $246^{\circ}$, respectively, and all had wind speeds close to $1 \mathrm{~m} / \mathrm{s}$. Three other cases featured variable wind direction over the course of the evening, making it dif- ficult to attribute a direction of approach of the plume (8, 11 and 26 March). The 17 March case involved a low wind speed of $0.5 \mathrm{~m} / \mathrm{s}$, likely indicating a stationary plume over the measurement site. Hence, the plumes did not appear to have a common origin based on the varying surface winds during the plume events.

Another PTR-MS instrument was located at the IMP for a limited amount of times during the campaign, when the Aerodyne mobile research laboratory parked there and provided data for intercomparison purposes. There was only one major toluene plume that was measured during the time when the Aerodyne van was located at the IMP (6 March 10:00-7 March 10:00 LT, 27 March 21:00-30 March 09:00 LT). The plume which occurred in the morning of 7 March was measured by both instruments, as shown in Fig. 5. The Aerodyne van PTR-MS measured fewer masses enabling a faster 


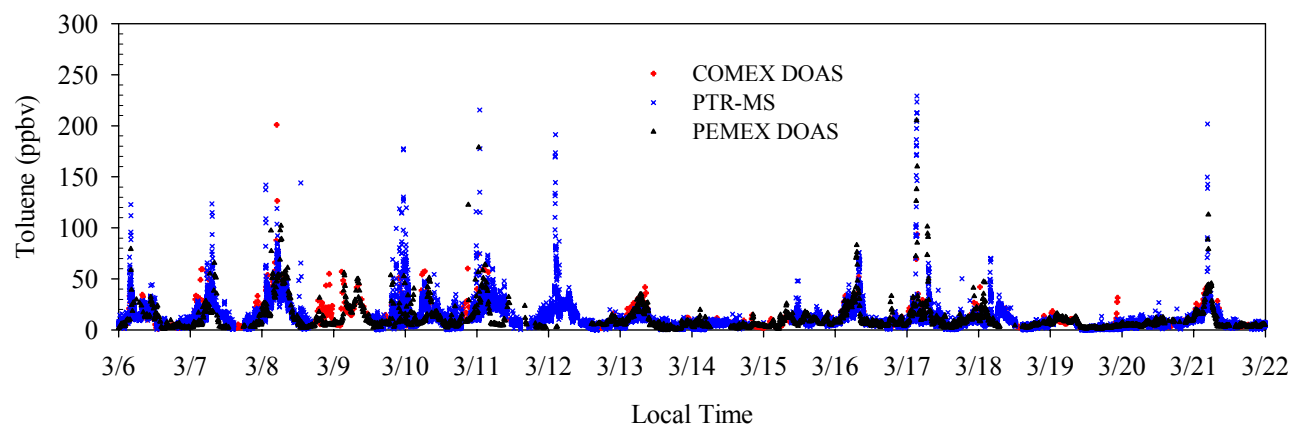

Fig. 6. Intercomparison of toluene observed at T0 by the PTR-MS and DOAS (two ground level light paths).

measuring cycle of $10 \mathrm{~s}$ explaining the greater frequency of measuring points within the plume measured by Aerodyne. The brief peak at $244 \mathrm{ppb}$ had a duration of only one cycle and obviously was not picked up by our PTR-MS with a measuring cycle of $76 \mathrm{~s}$. With the exception of this single point the toluene measurements of the two instruments were closely correlated. The Aerodyne mobile van was located on a surface street approximately one block to the West of the T0 building, where our PTR-MS conducted measurements. The difference in the locations of the two instruments excluded the possibility of local source contamination at either one of the two measuring sites.

Two long path DOAS instruments were also deployed at the T0 site to measure an array of VOCs including formaldehyde, glyoxal, and aromatic compounds. Details of the DOAS technique were described in Platt (1994) and Velasco (2007). Briefly, a DOAS system consists of a broadband UV/Vis light source, a retro reflector, and a CzernyTurner type spectrometer coupled to a 1024-element PDA detector. Light emitted from the light source is projected into the open air and reaches a distant retro reflector that returns the light right back into the instrument detector. Thus, DOAS can identify VOCs by their unique and specific UV absorption structures. Figure 6 shows the intercomparison of toluene measurements between the PTR-MS and two ground level DOAS light paths, T0-PEMEX and T0-COMEX, where PEMEX is $220 \mathrm{~m}$ to the west northwest of the T0 site and COMEX is $1026 \mathrm{~m}$ to the northwest of the T0 site. In general, all the three data sets agree with each other very well. Since DOAS is a spatially average data set, some toluene spikes might not be captured by the DOAS, e.g., on 10 March. Between the two DOAS data sets, the one with shorter light path match the PTR-MS better in time resolutions, especially the large spikes on 17 and 21 March. Also, VOC measurements were conducted using canisters (whole air samples) at T0 by the University of California - Irvine group. However, measurements using canisters had different time resolutions than those from PTR-MS and direct intercomparisons might not be straightforward.
For the determination of whether the source of these toluene peaks are industrial in nature or related to vehicular emissions, one analytical technique of common use is the comparison of ratios of aromatic compounds associated with vehicular use. The toluene/benzene ratio has been used to indicate the photochemical age of air masses with a major contribution from automobile emissions (Warneke et al., 2007), and this ratio can change significantly within a industrial toluene solvent plume (Rogers et al., 2006). We analyzed the ratio of toluene to benzene in an attempt to identify the origin of the toluene plumes observed during the MILAGRO 2006 campaign as either vehicular emissions or industrial emissions. A vehicular emission plume was usually encountered during rush hour and characterized by a relative low toluene/benzene ratio but an industrial plume was normally observed during midnight and distinguished by a much higher toluene/benzene ratio. Figure 7 depicts the ratio of toluene with benzene during the early morning toluene peak of 17 March as well as the peak which occurred around 07:00 LT on 7 March. Also shown in Fig. 7 are traces of toluene (red). Examination of the March 17 measurements shows clearly that the toluene plume is accompanied by an increase in the toluene/benzene ratio, indicating a likely industrial toluene source. On the other hand, for the plume on 7 March, both industrial and traffic sources were present. From 02:00 LT to 08:00 LT the toluene/benzene ratio shows a decreasing trend meanwhile toluene increase significantly and is consistent with the traffic rush hour (06:00 08:00 a.m. LT). A possible explanation is that the toluene plume on 7 March was first dominated by industrial sources and gradually switched to a rush hour traffic plume with some residue industrial plume keeping the toluene/benzene ratio higher than 5. Alternatively, the $\mathrm{VOC} / \mathrm{CO}$ ratio could provide information regarding to the emission sources. There were hourly $\mathrm{CO}$ concentration data at the T0 site, which could potentially be employed as an indicator of traffic vs. industrial sources. It should also be pointed out that the IMP site was strongly impacted by industry emissions and, therefore, might not be representative of the Mexico City as a whole. 

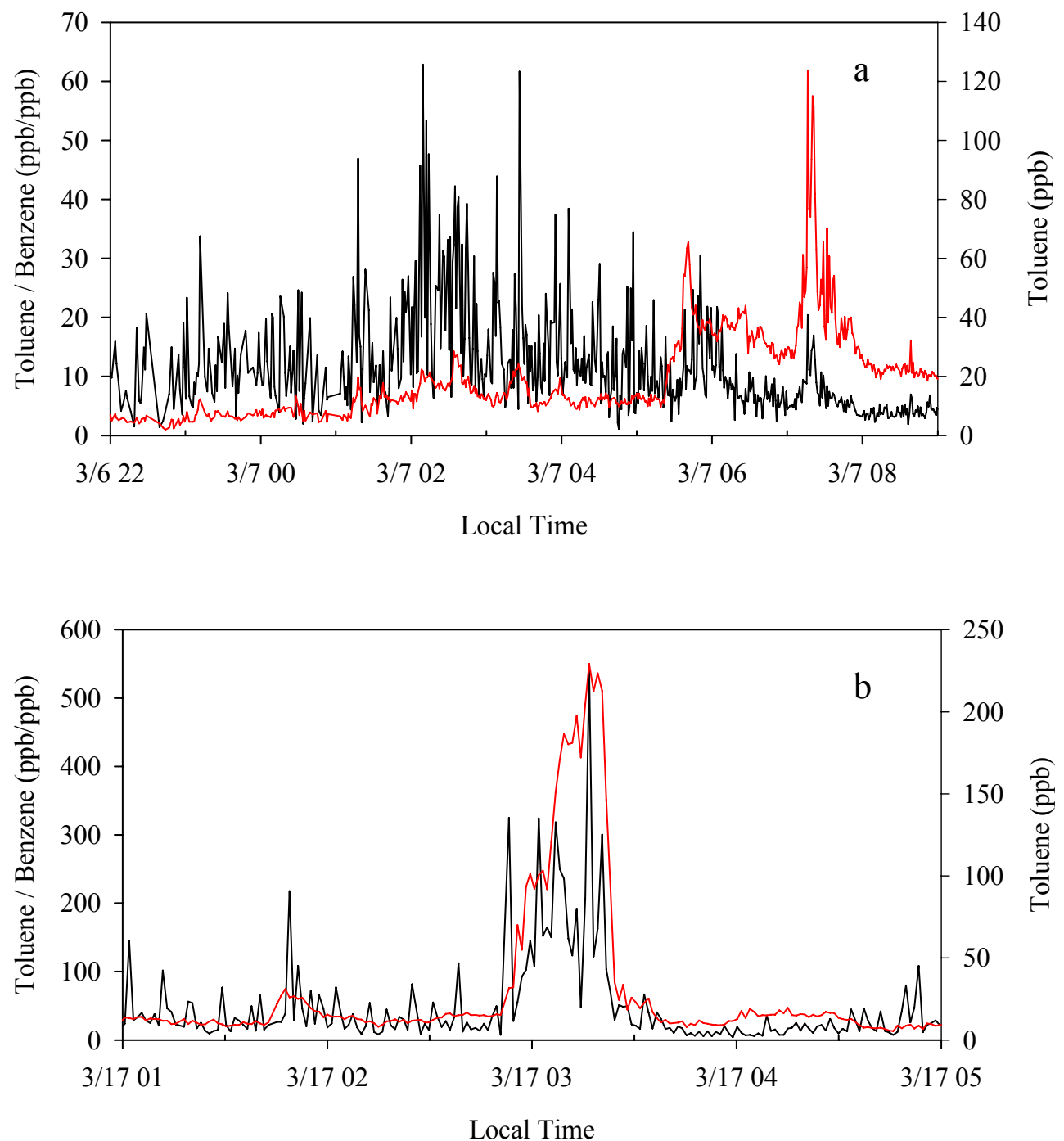

Fig. 7. Toluene (red line) and toluene/benzene ratio (black line) of (a) a morning traffic plume observed on 7 March and (b) a solvent plume observed on 17 March.

When considering the relevance of these plumes to the overall air pollution problem in Mexico City, it should be recognized that toluene is sufficiently active considering its reactivity with regard to $\mathrm{OH}$ (Picquet, 1998; Molina et al., 1999; Suh et al., 2002; Suh et al., 2003) and at a high enough mixing ratio it will contribute substantially to ozone and secondary organic aerosol production (Zhang et al., 2004b; Suh et al., 2006). Most of these plumes were measured at night with the exception of the 7 March case, which was measured during early daylight hours before the boundary layer had risen significantly. Clearly, the sources and impacts of those nighttime toluene plumes as relevant to ozone and secondary organic aerosol precursors need to be further evaluated in MCMA.

\subsection{Ethyl acetate}

A set of three masses (43, 61, and 89) demonstrated highly correlated peaks during the evening and early morning hours where they all rose by at least a factor of 10 relative to their baseline values for time periods ranging from $10 \mathrm{~min}$ to as long as $2 \mathrm{~h}$ periodically throughout the campaign. After post-field experimentation, it was determined that this signal, which was observed at masses 43,61 , and 89 , was attributable to ethyl acetate. Ethyl acetate has the atomic mass unit (amu) of 88 , leading to the proton transfer signal at 89 . As revealed from calibration conducted in our laboratory following the MILAGRO field campaign, ethyl acetate was found to fragment to masses 61 and 43. Using similar tunings and pressures as in MILAGRO, a sample of ethyl acetate (Sigma Aldrich) was found to fragment to mass 61 at $30 \%$ and mass 43 at $18 \%$, while the remaining $52 \%$ did not 
Table 2. Summary of occurrences of ethyl acetate plumes observed during MILAGRO 2006: The magnitudes, backgrounds (mixing ratios outside of the plume), wind direction, wind speed, time of occurrence, duration, date and day of week pertaining to the ten highest peaks.

\begin{tabular}{|c|c|c|c|c|c|c|c|}
\hline Mixing Ratio (ppb) & Baseline (ppb) & Date (Mar) & Local Time & Duration (min) & Day & Wind Dir. (Degree) & Wind Speed $(\mathrm{m} / \mathrm{s})$ \\
\hline 202 & 19 & 29 & 05:51-06:14 a.m. & 23 & Wednesday & 224 & 1 \\
\hline 152 & 15 & 17 & 02:03-02:58 a.m. & 55 & Friday & 236 & 0.74 \\
\hline 142 & 10 & 16 & 03:32-05:44 a.m. & 132 & Thursday & 232 & 0.65 \\
\hline 142 & 27 & 29 & 03:41-04:19 a.m. & 38 & Wednesday & 215 & 0.7 \\
\hline 127 & 23 & 31 & 01:27-02:05 a.m. & 38 & Friday & N/A & N/A \\
\hline 125 & 27 & 31 & 04:21-04:47 a.m. & 26 & Friday & N/A & N/A \\
\hline 121 & 12 & 23 & 05:25-05:36 a.m. & 11 & Thursday & 194 & 0.45 \\
\hline 119 & 18 & 23 & 03:25-03:57 a.m. & 32 & Thursday & 246 & 1.19 \\
\hline 117 & 29 & 29 & $02: 15-02: 45$ a.m. & 30 & Wednesday & 241 & 1.06 \\
\hline 102 & 25 & 21 & 05:04-05:20 a.m. & 16 & Tuesday & 258 & 0.94 \\
\hline
\end{tabular}
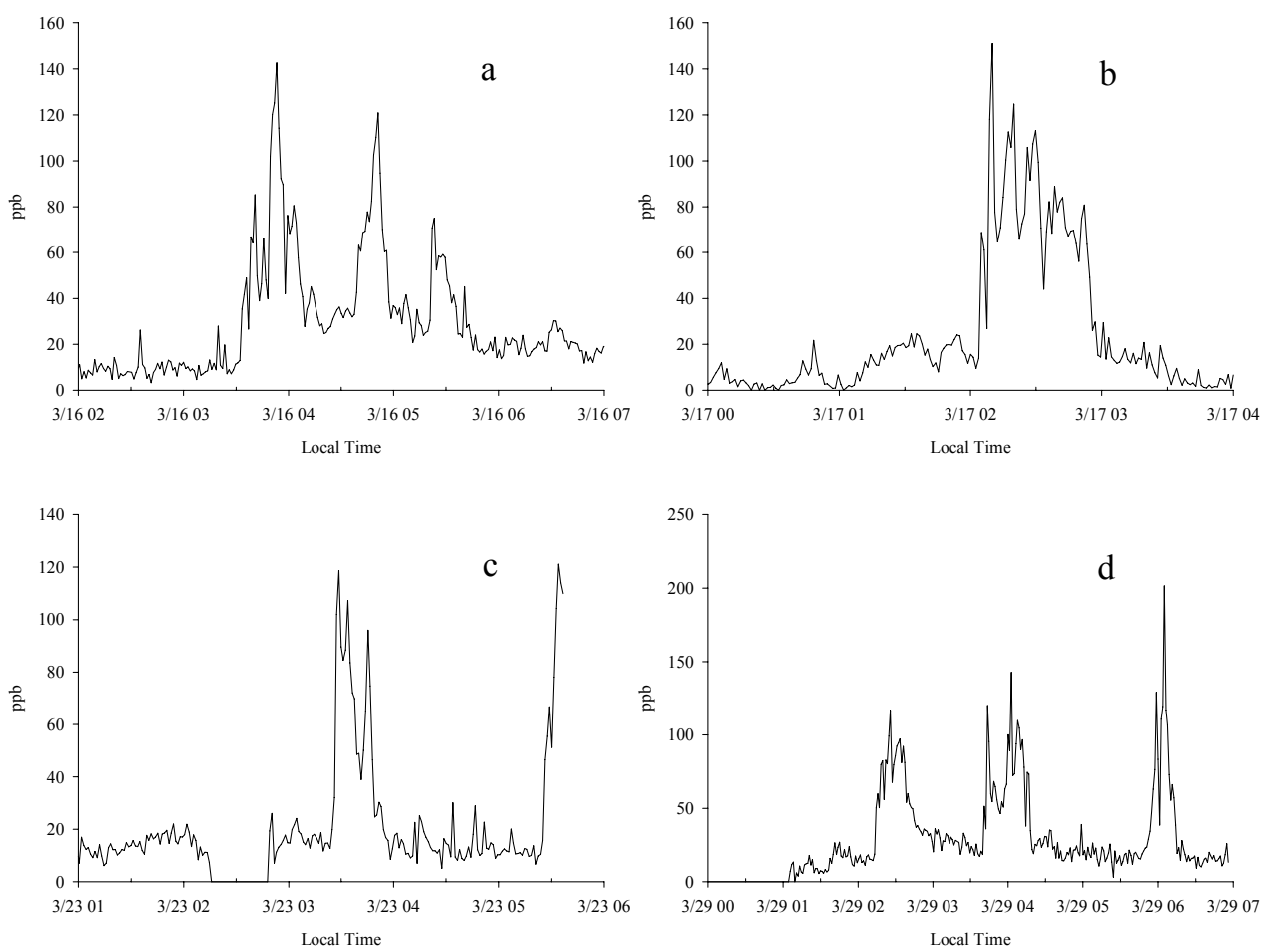

Fig. 8. Four ethyl acetate plumes observed during the MILAGRO 2006 at T0 on 16 (a), 17 (b), 23 (c), and 29 (d) March.

fragment and was measured at mass 89 . Thus, the concentration of mass 89 in this work has been adjusted to account for the fragmentation loss, as verified in our laboratory experiment. Previous studies, which did not evaluate all VOCs but rather a limited number (Warneke et al., 2003), did not show any compound fragmenting to mass 89 . It is also noteworthy that none of the other 35 masses being measured showed any correlation with mass 89 , which would have indicated possible fragmentation from higher masses.

Mixing ratios of ethyl acetate higher than $50 \mathrm{ppb}$ were encountered for 9 of the 17 evenings that the PTR-MS sampled mass 89 . This mass was not sampled during the first few days of the campaign. Table 2 summarizes the peak concentration, time of occurrence, duration, and date and day of week pertaining to the mass 89 peaks with the ten highest magnitudes. An analysis of the times of occurrence of these plumes and the winds associated with them will allow for some insights regarding the source of the ethyl acetate plumes.

The top ten ethyl acetate peaks all happened during the early morning hours between 01:00-07:00 LT on weekdays, except one of these mornings was a holiday. Despite the fact that the highest peaks primarily occurred on weekdays, the diurnal averages discussed earlier show that ethyl acetate concentrations were quite high on weekend/holiday 

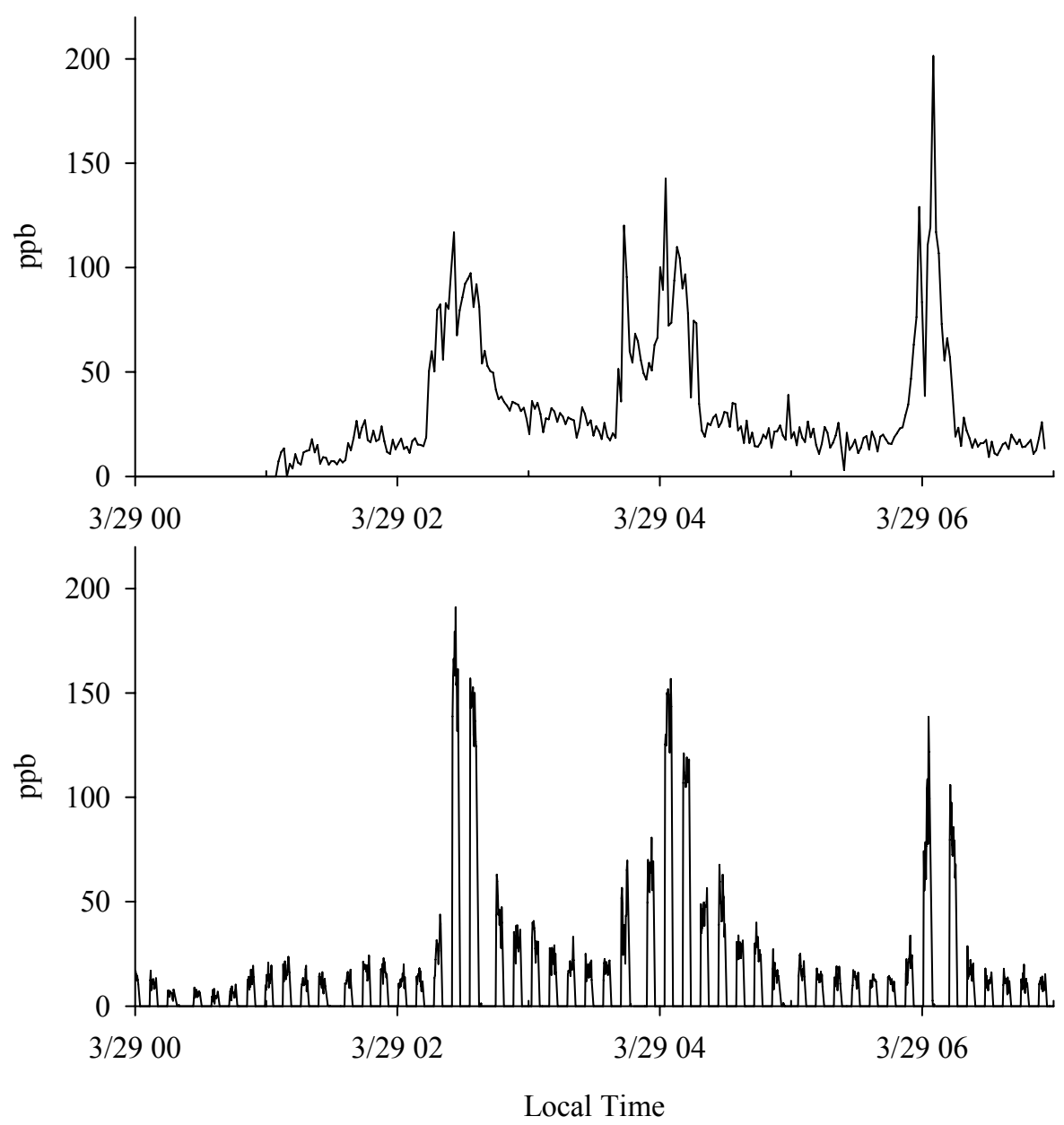

Fig. 9. Intercomparison of ethyl acetate observed at T0 (a) and on the Aerodyne Mobile Lab (b) on March 29. Gaps in (b) were due to background checks.

early morning periods. Four of these peaks occurred at least partially during the transitional time period between 05:0006:00 LT when traffic generally switched from light to heavy and one of these four extended into the heavy traffic time period after 06:00 LT. $60 \%$ of the plumes occurred during periods of light traffic earlier than 05:00 LT.

A series of temporal changes in mass 89 signals for the evenings is displayed in Fig. 8. On all four evenings there was a wind from approximately a $250^{\circ}$ heading for a large portion of the evening including the bulk of the time periods when most peaks occurred. Examination of the meteorology conditions also revealed that during many of the ethyl acetate plume episodes when winds were light $(<0.5 \mathrm{~m} / \mathrm{s})$ there was a tendency of the wind gauge to turn to approximately a $100^{\circ}$ heading (which was a somewhat debatable measurement due to the low wind speed but nonetheless slightly skews the average wind direction). These plumes likely originated from a specific area, which seemed to have been located at around a $230-260^{\circ}$ heading from the IMP facility, although it was pos- sible that the plumes were evolving during transport. Further studies focusing on the industrial areas to the Southwest and West of the facility will help to isolate the sources of these plumes.

The Aerodyne mobile van was located at the IMP during the time period of the ethyl acetate peaks that were encountered on 29 March. Figure 9 shows the mass 89 measurement results of both instruments during the early morning hours of 29 March. The Aerodyne van did not continuously monitor mass 89 preferring instead to measure mass 89 once every few minutes as part of a spectral scan explaining the gaps in the data on the Aerodyne measurement. The two instruments detected the three separate peaks on that evening and the magnitudes of the three peaks were similar. The data gaps in the Aerodyne data leave out some plume detail, which should be considered when comparing the relative magnitudes of the peaks with each system. 
When considering the relevance of these ethyl acetate peaks to the urban air pollution problem in Mexico City, it is important to note that ethyl acetate has an $\mathrm{OH}$ reaction rate coefficient of $\left(1.7 \times 10^{-12} \mathrm{~cm}^{3}\right.$ molecule ${ }^{-1} \mathrm{~s}^{-1}$ ), which is comparable to that of ethylene $\left(8.5 \times 10^{-12} \mathrm{~cm}^{3}\right.$ molecule $\left.{ }^{-1} \mathrm{~s}^{-1}\right)$ (Atkinson, 1994). The peak that occurred at 06:00 on 29 March was observed within an hour of sunrise and was $95 \mathrm{ppb}$ above the background level and would been a significant source of ozone precursors.

\section{Conclusions}

A large number of ambient VOC concentrations were measured by a PTR-MS instrument on a rooftop in the urban mixed residential and industrial area North Northeast of downtown Mexico City as part of the MILAGRO 2006 campaign, with the purpose to gain a better understanding of the type of VOC species present in the particular area of the MCMA. The primary objective of this paper is to present the general characteristic of VOCs at T0 site during the campaign.

The highest average VOC concentrations that PTR-MS measured were from methanol. Methanol peaks averaged approximately $50 \mathrm{ppb}$ during the morning rush hour time period. Aromatics were the second most abundant class of species measured by PTR-MS with toluene, $\mathrm{C}_{2}$ benzenes and $\mathrm{C}_{3}$ benzenes averaging 26,18 and $11 \mathrm{ppb}$, respectively, during the morning rush hour. The oxygenated VOC acetaldehyde was also found to peak at approximately $12 \mathrm{ppb}$ on average during the late morning hours. Both isoprene and monoterpenes were not likely biogenic in origin. Possible sources include automobile exhausts, biomass burning processes, and industrial emissions.

The diurnal patterns indicate that the highest mixing ratios of most VOCs were found between 06:00-09:00 LT and the VOC concentrations decreased as the boundary layer rose during the mid-morning timeframe. No afternoon VOC peak was observed. Aromatic VOC mixing ratios maintained at a higher level on weekdays than on weekend/holidays throughout the day indicating a possible traffic influence. The diurnal patterns of toluene and ethyl acetate indicated that industrial nighttime emissions of these species were significant in the area around the IMP facility.

Plumes of highly elevated VOC concentrations of toluene and ethyl acetate were observed during the late night and early morning hours. These plumes were elevated as much as 216 and $183 \mathrm{ppb}$ and had time durations varying from $10 \mathrm{~min}$ to $2 \mathrm{~h}$. These plumes were also measured by another PTRMS instrument in the Aerodyne mobile research van when it was parked at the IMP facility approximately one block west of the T0 location at the surface street level. An analysis of surface winds coinciding with the time of the toluene plumes revealed no preferred wind direction matching these peaks and therefore the toluene plumes were not attributed to a single source or even a single area. A comparison with other aromatics at the time of the toluene peaks indicated primarily no correlation although one of the $\mathrm{C}_{2}$ benzenes showed a correlation at times. An analysis of the surface winds present during the time of the ethyl acetate plumes indicated that the winds were limited to a range of $230-260^{\circ}$ leading to the preliminary conclusion that the ethyl acetate source was from a particular area to the Southwest or West of the IMP facility. A stable nocturnal planetary boundary layer likely facilitated accumulation of VOCs and more highly elevated VOC plumes at nighttime.

The impacts of the toluene and ethyl acetate plumes relevant to ozone and secondary organic aerosol formation in this area need to be further assessed. Also, further work to integrate the present measurements with other VOC measurements conducted during the MILAGRO 2006 campaign is required to develop a better understanding of the overall spatial pattern of VOCs and its variability in the MCMA.

Acknowledgements. This research was funded by the Center for Atmospheric Chemistry and Environment at the Texas A\&M University and by the Robert A. Welch Foundation (Grant A-1417). The authors were grateful to Nancy A. Marley and Jeffrey S. Gaffney for providing the temperature, wind and RH data. L.T.M. acknowledged support from NSF (ATM-0528227).

Edited by: S. Madronich

\section{References}

Arriaga-Colina, J. L., West, J. J., Sosa, G., Escalona, S. S., Ordunez, R. M., and Cervantes, A. D. M.: Measurements of VOCs in Mexico City (1992-2001) and evaluation of VOCs and CO in the emissions inventory, Atmospheric Environment, 38, 25232533, doi:10.1016/j.atmosenv.2004.01.033, 2004.

Atkinson, R.: Gas-Phase Tropospheric Chemistry of OrganicCompounds, Journal of Physical and Chemical Reference Data, 2, 11-216, 1994.

CAM (Comisión Ambiental Metropolitana): Inventario de emisiones a la atmósfera, Zona Metropolitana del Valle México, 1998, 2001.

CAM (Comisión Ambiental Metropolitana): Inventario de emisiones 2004 de la Zona Metropolitana del Valle de México, Secretaría del Medio Ambiente, Gobierno de México, México, available online at: http://www.sma.df.gob.mx/, 2006.

Christian, T. J., Kleiss, B., Yokelson, R. J., Holzinger, R., Crutzen, P. J., Hao, W. M., Shirai, T., and Blake, D. R.: Comprehensive laboratory measurements of biomass-burning emissions: 2. First intercomparison of open-path FTIR, PTR-MS, and GC- MS/FID/ECD, J. Geophys. Res.-Atmos., 109, D02311, doi:10.1029/2003JD003874, 2004.

de Foy, B., Caetano, E., Magana, V., Zitacuaro, A., Cardenas, B., Retama, A., Ramos, R., Molina, L. T., and Molina, M. J.: Mexico City basin wind circulation during the MCMA-2003 field campaign, Atmos. Chem. Phys., 5, 2267-2288, 2005, http://www.atmos-chem-phys.net/5/2267/2005/. 
de Gouw, J., Warneke, C., Karl, T., Eerdekens, G., van der Veen, C., and Fall, R.: Sensitivity and specificity of atmospheric trace gas detection by proton-transfer-reaction mass spectrometry, International Journal of Mass Spectrometry, 223, 365-382, Pii S13873806(02)00926-0, 2003a.

de Gouw, J. A., Goldan, P. D., Warneke, C., Kuster, W. C., Roberts, J. M., Marchewka, M., Bertman, S. B., Pszenny, A. A. P., and Keene, W. C.: Validation of proton transfer reaction-mass spectrometry (PTR-MS) measurements of gas-phase organic compounds in the atmosphere during the New England Air Quality Study (NEAQS) in 2002, J. Geophys. Res.-Atmos., 108(D21), 4682, doi:10.1029/2003jd003863, 2003 b.

de Gouw, J. and Warneke, C.: Measurements of volatile organic compounds in the earth's atmosphere using proton-transferreaction mass spectrometry, Mass Spectrom. Rev., 26, 223-257, 2007.

Fan, J. W., Zhao, J., and Zhang, R.: Theoretical study of $\mathrm{OH}$ addition to alpha-pinene and beta-pinene, Chem. Phys. Lett., 411, 1-7, doi:10.1016/j.cplett.2005.05.122, 2005.

Fortner, E. C., Zhao, J., and Zhang, R. Y.: Development of ion drift-chemical ionization mass spectrometry, Anal. Chem., 76, 5436-5440, doi:10.1021/Ac0493222, 2004.

Instituto Nacional de Ecologia: Gestión de la calidad del aire en México, Logros y Retos para el Desarrollo Sustentable 19952000. Instituto Nacional de Ecología, México, 2000.

Karl, T., Fall, R., Crutzen, P. J., Jordan, A., and Lindinger, W.: High concentrations of reactive biogenic VOCs at a high altitude site in late autumn, Geophys. Res. Lett., 28, 507-510, 2001.

Lei, W., Zhang, R., McGivern, W. S., Derecskei-Kovacs, A., and North, S. W.: Theoretical study of isomeric branching in the isoprene-OH reaction: Implications to final product yields in isoprene oxidation, Chem. Phys. Lett., 326, 109-114, 2000.

Lei, W. F., Zhang, R., Tie, X. X., and Hess, P.: Chemical characterization of ozone formation in the Houston-Galveston area: A chemical transport model study, J. Geophys. Res.-Atmos., 109, D12301, doi:10.1029/2003jd004219, 2004.

Lei, W., de Foy, B., Zavala, M., Volkamer, R., and Molina, L. T.: Characterizing ozone production in the Mexico City Metropolitan Area: a case study using a chemical transport model, Atmos. Chem. Phys., 7, 1347-1366, 2007,

http://www.atmos-chem-phys.net/7/1347/2007/.

Li, G. H., Zhang, R., Fan, J. W., and Tie, X. X.: Impacts of biogenic emissions on photochemical ozone production in Houston, Texas, J. Geophys. Res.-Atmos., 112, D10309, doi:10.1029/2006jd007924, 2007.

Molina, M. J., Zhang, R., Broekhuizen, K., Lei, W., Navarro, R., and Molina, L. T.: Experimental study of intermediates from $\mathrm{OH}$-initiated reactions of toluene, J. Am. Chem. Soc., 121, 10225-10226, 1999.

Molina, M. J., Molina, L. T., West, J. J., Sosa, G., Sheinbaum, C., San Martini, F., Zavala, M. A., and McRae, G.: Air pollution science in the MCMA: understanding source-receptor relationships through emissions inventories, measurements and modeling, in: Air Quality in the Mexico Megacity: An Integrated Assessment, edited by: Molina, L. T. and Molina, M. J., 137-212, Kluwer Acad., Norwell, MA, USA, 2002.

Molina, L. T., Madronich, S., Gaffney, J. S., and Singh, H. B.: Overview of MILAGRO/INTEX-B Campaign, IGAC Newsletter, Issue No. 38, 2-15, 2009.
Picquet, B., Heroux, S., Chebbi, A., Doussin, J. F., Durand-Jolibois, R., Monod, A., Loirat, H., and Carlier, P.: Kinetics of the reactions of $\mathrm{OH}$ radicals with some oxygenated volatile organic compounds under simulated atmospheric conditions, Int. J. Chem. Kinet., 30, 839-847, 1998.

Platt, U.: Differential optical absorption spectroscopy, in: Monitoring by Spectroscopic Techniques, edited by: Sigrist, M. W. chap. 2, 27-84, John Wiley, Hoboken, NJ, USA, 1994.

Rogers, T. M., Grimsrud, E. R., Herndon, S. C., Jayne, J. T., Kolb, C. E., Allwine, E., Westberg, H., Lamb, B. K., Zavala, M., Molina, L. T., Molina, M. J., and Knighton, W. B.: On-road measurements of volatile organic compounds in the Mexico City metropolitan area using proton transfer reaction mass spectrometry, Int. J. Mass Spectrom., 252, 26-37, 2006.

Shaw, W. J., Pekour, M. S., Coulter, R. L., Martin, T. J., and Walters, J. T.: The daytime mixing layer observed by radiosonde, profiler, and lidar during MILAGRO, Atmos. Chem. Phys. Discuss., 7, 15025-15065, 2007, http://www.atmos-chem-phys-discuss.net/7/15025/2007/.

Stephens, S., Madronich, S., Wu, F., Olson, J., Ramos, R., Retama, A., and Muñoz, R.: Weekly patterns of Mexico City's surface concentrations of $\mathrm{CO}, \mathrm{NO}_{\mathrm{x}}, \mathrm{PM}_{10}$, and $\mathrm{O}_{3}$ during 1986-2007, Atmos. Chem. Phys., 8, 5313-5325, 2008, http://www.atmos-chem-phys.net/8/5313/2008/.

Suh, I., Lei, W., and Zhang, R.: Experimental and theoretical studies of isoprene reaction with $\mathrm{NO}_{3}$, J. Phys. Chem., 105, 64716478, 2001.

Suh, I., Zhang, D., Zhang, R., Molina, L. T., and Molina, M. J.: Theoretical study of $\mathrm{OH}$ addition reaction to toluene, Chem. Phys. Lett., 364, 454-462, 2002.

Suh, I., Zhang, R. , Molina, L. T., and Molina, M. J.: Oxidation mechanism of aromatic peroxy and bicyclic radicals from $\mathrm{OH}-$ toluene reactions, J. Am. Chem. Soc., 125, 12655-12665, 2003.

Suh, I., Zhao, J., and Zhang, R.: Unimolecular decomposition of aromatic bicyclic alkoxy radicals and their acyclic radicals, Chem. Phys. Lett., 432, 313-320, 2006.

Tie, X., Zhang, R., Brasseur, G., Emmons, L., and Lei, W.: Effects of lightning on reactive nitrogen and nitrogen reservoir species, J. Geophys. Res., 106, 3167-3178, 2001.

Tie, X. X., Madronich, S., Li, G. H., Ying, Z. M., Zhang, R., Garcia, A. R., Lee-Taylor, J., and Liu, Y. B.: Characterizations of chemical oxidants in Mexico City: A regional chemical dynamical model (WRF-CHEM) study, Atmos. Environ., 41, 1989-2008, 2007.

Velasco, E., Lamb, B., Pressley, S., Allwine, E., Westberg, H., Jobson, B. T., Alexander, M., Prazeller, P., Molina, L., and Molina, M.: Flux measurements of volatile organic compounds from an urban landscape, Geophys. Res. Lett., 32, L20802, doi:10.1029/2005g1023356, 2005.

Velasco, E., Lamb, B., Westberg, H., Allwine, E., Sosa, G., ArriagaColina, J. L., Jobson, B. T., Alexander, M. L., Prazeller, P., Knighton, W. B., Rogers, T. M., Grutter, M., Herndon, S. C., Kolb, C. E., Zavala, M., de Foy, B., Volkamer, R., Molina, L. T., and Molina, M. J.: Distribution, magnitudes, reactivities, ratios and diurnal patterns of volatile organic compounds in the Valley of Mexico during the MCMA 2002 \& 2003 field campaigns, Atmos. Chem. Phys., 7, 329-353, 2007, http://www.atmos-chem-phys.net/7/329/2007/.

Warneke, C., De Gouw, J. A., Kuster, W. C., Goldan, P. D., 
and Fall, R.: Validation of atmospheric VOC measurements by proton-transfer-reaction mass spectrometry using a gaschromatographic preseparation method, Environ. Sci. Technol., 37, 2494-2501, doi:10.1021/Es026266i, 2003.

Warneke, C., McKeen, S. A., de Gouw, J. A., Goldan, P. D., Kuster, W. C., Holloway, J. S., Williams, E. J., Lerner, B. M., Parrish, D. D., Trainer, M., Fehsenfeld, F. C., Kato, S., Atlas, E. L., Baker, A., and Blake, D. R.: Determination of urban volatile organic compound emission ratios and comparison with an emissions database, J. Geophys. Res.-Atmos., 112, D10S47, doi:10.1029/2006JD007930, 2007.

West, J. J., Zavala, M. A., Molina, L. T., Molina, M. J., San Martini, F., McRae, G. J., Sosa-Iglesias, G., and Arriaga-Colina, J. L.: Modeling ozone photochemistry and evaluation of hydrocarbon emissions in the Mexico City metropolitan area, J. Geophys. Res.-Atmos., 109, D19312, doi:10.1029/2004jd004614, 2004.

Zhang, D., Zhang, R., Park, J., and North, S. W.: Hydroxyperoxy nitrites and nitrates from $\mathrm{OH}$ initiated reactions of isoprene, J. Am. Chem. Soc., 124, 9600-9605, 2002a.

Zhang, D., Lei, W., and Zhang, R.: Mechanism of $\mathrm{OH}$ formation from ozonolysis of isoprene: Kinetics and product yields, Chem. Phys. Lett., 358, 171-179, 2002b.

Zhang, R., Tie, X., and Bond, D. W.: Impacts of anthropogenic and natural $\mathrm{NO}_{\mathrm{X}}$ sources over the U.S. on tropospheric chemistry, $\mathrm{P}$. Natl. Acad. Sci. USA, 100, 1505-1509, 2003.
Zhang, R. Y., Lei, W. F., Tie, X. X., and Hess, P.: Industrial emissions cause extreme urban ozone diurnal variability, P. Natl. Acad. Sci. USA, 101, 6346-6350, 2004a.

Zhang, R. Y., Suh, I., Zhao, J., Zhang, D., Fortner, E. C., Tie, X. X., Molina, L. T., and Molina, M. J.: Atmospheric new particle formation enhanced by organic acids, Science, 304, 1487-1490, 2004 b.

Zhao, J. and Zhang, R. Y.: Proton transfer reaction rate constants between hydronium ion $(\mathrm{H} 3 \mathrm{O}(+))$ and volatile organic compounds, Atmos. Environ., 38, 2177-2185, 2004a.

Zhao, J., Zhang, R. Y., Fortner, E. C., and North, S. W.: Quantification of hydroxycarbonyls from $\mathrm{OH}$-isoprene reactions, J. Am. Chem. Soc., 126, 2686-2687, 2004b.

Zhao, J., Zhang, R. Y., Misawa, K., and Shibuya, K.: Experimental product study of the $\mathrm{OH}$-initiated oxidation of m-xylene, J. Photochem. Photobiol. Chem., 176, 199-207, 2005.

Zheng, J., R. Zhang, E. C. Fortner, R. M. Volkamer, L. Molina, A. C. Aiken, J. L. Jimenez, K. Gaeggeler, J. Dommen, S. Dusanter, P. S. Stevens, and X. Tie: Measurements of $\mathrm{HNO}_{3}$ and $\mathrm{N}_{2} \mathrm{O}_{5}$ using ion drift - chemical ionization mass spectrometry during the MCMA - 2006 campaign, Atmos. Chem. Phys., 8, 68236838, 2008, http://www.atmos-chem-phys.net/8/6823/2008/. 